\title{
Implementasi Metode Webqual 4.0 Untuk Mengukur Kualitas Website UPT Perpustakaan UNILA
}

\author{
Gisella Roliani, ${ }^{2}$ Tristiyanto, ${ }^{3}$ Yunda Heningtyas \\ 1,2,3 Jurusan Ilmu Komputer, Fakultas Matematika dan Ilmu Pengetahuan Alam, Universitas Lampung \\ Email: ${ }^{1}$ gisella.roliani03@gmail.com. ${ }^{2}$ tristiyanto.1981@ fmipa.unila.ac.id. \\ ${ }^{3}$ yunda.heningtyas89@gmail.com
}

\begin{abstract}
Library integrated service unit of Unila provides academic services for students through the website. The quality of the website has never been evaluated based on student perceptions. This research discusses the quality measurement of library integrated service unit of Unila's website using webqual 4.0 method. The purpose of this research is to determine the variable webqual 4.0 that affect student satisfaction. Data analysis method used is Structural Equation Modeling (SEM) with Partial Least Square (PLS) approach. The results of this research are the factors that most influence student satisfaction are information quality and usability.
\end{abstract}

Keywords: evaluation of website quality, partial least square (PLS), Structural Equation Modeling (SEM), student satisfaction, webqual 4.0 method

\section{Pendahuluan}

Universitas Lampung telah menerapkan penggunaan website untuk meningkatkan layanan akademik kepada mahasiswa. Salah satu layanan yang telah menggunakan website tersebut adalah UPT Perpustakaan UNILA. Dengan adanya website tersebut mahasiswa dapat mencari informasi dengan mudah seperti informasi mengenai profil, pendaftaran kartu anggota perpustakaan, pengembalian buku, dan lain sebagainya.

Selama website UPT Perpustakaan UNILA diimplementasikan, belum pernah dilakukan evaluasi terhadap kualitas website tersebut. Oleh sebab itu, UPT Perpustakaan UNILA perlu melakukan evaluasi terhadap kualitas website berdasarkan persepsi mahasiswa. Semakin baik kualitas layanan suatu website, semakin besar tingkat kepuasan seseorang. Semakin besar tingkat kepuasan seseorang akan suatu layanan website, semakin tinggi intensitas seseorang menggunakan layanan tersebut[1].

Pengukuran kualitas website dapat dilakukan menggunakan metode webqual 4.0. Webqual 4.0 merupakan metode yang dapat digunakan untuk mengukur kualitas website berdasarkan persepsi pengguna atau pengunjung[2]. Pengukuran kualitas menggunakan metode webqual 4.0, dilakukan pada 3 dimensi. Ketiga dimensi tersebut adalah kegunaan (usability), kualitas informasi (information quality), dan kualitas interaksi layanan (service interaction quality)[3].

Penelitian-penelitian yang berhubungan dengan webqual menjadi rujukan dalam penelitian ini. Metode webqual telah diterapkan untuk mengevaluasi kepuasan pengguna pada sistem perpustakaan di bursa efek Thailand. Webqual juga digunakan untuk mengetahui hubungan antara kepuasan pengguna dengan dimensi webqual. Hasil penelitian menyebutkan bahwa kepuasan pengguna sangat kuat dipengaruhi oleh dimensi kegunaan seperti website mudah dipelajari, mudah dioperasikan, atraktif penampilan, desain website, menyampaikan rasa kompetensi dan pengalaman positif pengguna[4]. 
Selain itu, instrument webqual telah dikembangkan dengan menguji 4 website sekolah bisnis di Inggris yaitu Bath, London (LBS), Manchester (MBS), dan Warwick (WBS). Hasil penelitian menunjukkan Bath memiliki kualitas website yang lebih baik dari pada ketiga website lainnya. Selain itu, penelitian tersebut dapat disimpulkan bahwa instrument yang ada di webqual memiliki validitas, meskipun dibutuhkan pengujian lebih lanjut dengan sampel yang besar dan beragam[5].

\section{Metode Penelitian}

Penelitian ini menggunakan tiga variabel independen dan satu variabel dependen. Variabelvariabel independen meliputi kualitas kegunaan (usability), kualitas informasi (information quality), dan kualitas interaksi layanan (service interaction quality). Variabel dependen meliputi kepuasan pengguna (user satisfaction).

Variabel kegunaan (usability) didefinisikan sebagai kualitas yang berkaitan dengan desain website dan kegunaan, misalnya penampilan, kemudahan penggunaan, navigasi, dan gambaran yang disampaikan untuk pengguna[3]. Variabel kualitas informasi (information quality) didefinisikan sebagai kualitas yang berkaitan dengan konten website, kesesuaian informasi untuk tujuan pengguna, misalnya akurasi, format, dan relevansi[3]. Variabel kualitas interaksi layanan (service interaction quality) didefinisikan sebagai kualitas interaksi layanan yang dialami pengguna ketika mereka menggali lebih dalam sebuah website, diwujudkan dengan kepercayaan dan empati, misalnya masalah transaksi dan informasi keamanan, personalisasi, dan komunikasi dengan pemilik situs[3]. Variabel kepuasan pengguna (user satisfaction) didefinisikan sebagai pendapat atau persepsi pengguna mengenai kepuasan secara keseluruhan dan kesuksesan website[6].

Kualitas kegunaan berpengaruh terhadap kepuasan pengguna. Tingkat kualitas kegunaan sangat penting untuk mencapai kepuasan pengguna. Kualitas kegunaan yang dimaksud adalah alamat website yang relative mudah diingat, terorganisir dengan baik, terstruktur dengan baik, mudah untuk dinavigasi, isinya ringkas dan mudah dimengerti, memiliki interface yang baik dan mudah digunakan oleh pengguna[7]. Oleh sebab itu, hipotesis pertama yang diajukan dalam penelitian ini adalah sebagai berikut:

$\mathrm{H}_{1}$ : Terdapat hubungan antara kegunaan (usability) dengan kepuasan pengguna (user satisfaction)

Kualitas informasi berpengaruh terhadap kepuasan pengguna. Pernyataan tersebut menunjukkan bahwa pengguna tidak akan puas dengan suatu website jika tidak adanya informasi yang akurat, tepat waktu, sesuai format, lengkap, ringkas, dan relevan. Sehingga, kualitas informasi dari suatu website sangat penting demi kepentingan pengguna[8]. Selain itu, kualitas informasi dianggap penting karena memberikan informasi yang berkualitas kepada pengguna secara konsisten dipandang sebagai penentu utama website tersebut dapat diterima oleh pengguna[9]. Berdasarkan uraian tersebut, hipotesis kedua yang diajukan adalah sebagai berikut:

$\mathrm{H}_{2}$ : Terdapat hubungan antara kualitas informasi (information quality) dengan kepuasan pengguna (user satisfaction)

Kualitas interaksi layanan berpengaruh terhadap kepuasan pengguna. Kualitas layanan website didefinisikan dengan perasaan nyaman pengguna saat berinteraksi dengan website. Selain itu, pengguna merasa puas jika website dapat menjaga keamanan informasi dan informasi pribadi pengguna[7]. Semakin tinggi rating kualitas layanan, semakin tinggi kepuasan pengguna terhadap website tersebut[8]. Berdasarkan uraian tersebut, hipotesis ketiga yang diajukan adalah sebagai berikut: 
$\mathrm{H}_{3}$ : Terdapat hubungan antara kualitas interaksi layanan (service interaction quality) dengan kepuasan pengguna (user satisfaction)

Berdasarkan tiga hipotesis diatas, maka kerangka pemikiran dalam penelitian ini dapat dilihat pada Gambar 1.

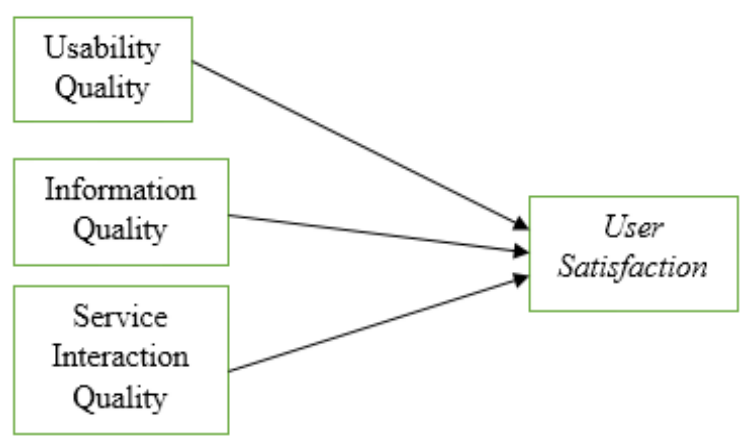

Gambar 1. Kerangka Pemikiran.

Populasi yang menjadi unit evaluasi dalam penelitian ini adalah seluruh mahasiswa di Fakultas Matematika dan Ilmu Pengetahuan Alam (FMIPA) UNILA. Jumlah sampel yang digunakana dalam SEM-PLS adalah 10 sampel untuk tiap jalur[10]. Penelitian ini memiliki 3 jalur dalam kerangka peneltian. Sehingga, jumlah minimal sampel yang digunakan yaitu 30 sampel. Teknik pengambilan sampel yang digunakan adalah purposive sampling, dengan kriteria responden pernah mengakses website UPT Perpustakaan UNILA.

Kuesioner merupakan instrumen penting yang digunakan pada penelitian ini. Kuesioner memuat 24 pertanyaan yang mewakili seluruh variabel untuk mengetahui penilaian responden terhadap website UPT Perpustakaan UNILA. Skala likert yang digunakan dalam kuesioner dimulai dari skala 1 sampai dengan 5. Penyebaran kuesioner pada penelitian ini dilakukan secara online.

Metode analisis data yang digunakan pada penelitian ini yaitu Structural Equation Model (SEM) menggunakan pendekatan Partial Least Square (PLS) dan SmartPLS versi 2 sebagai softwarenya. PLS merupakan pengujian model prediksi yang bertujuan untuk menguji hubungan atau pengaruh antara variabel-variabel yang ada pada sebuah model. Evaluasi model PLS dilakukan dengan mengevaluasi model pengukuran (outer model) dan model struktural (inner model).

Model pengukuran (outer model) digunakan untuk menguji validitas konstruk (konvergen dan diskriminan) dan reliabilitas konstruk. Parameter uji validitas konvergen dilihat dari nilai AVE dan communality, masing-masing harus bernilai diatas 0,5. Parameter uji validitas diskriminan dilihat dari nilai cross loading dengan ketentuan masing-masing indikator disuatu konstruk harus berbeda dengan indikator di konstruk lain. Perbedaan tersebut dilihat dari nilai indikator disuatu konstruk harus lebih tinggi daripada indikator di konstruk lain. Pengujian reliabilitas dilihat dari nilai cronbach's alpha dan composite reliability. Suatu konstruk dikatakan reliable, apabila memiliki nilai cronbach's alpha $>0,6$ dan nilai composite reliability $>0,7[10]$.

Model struktural (inner model) dalam PLS dievaluasi menggunakan Coefficient of Determinant $\left(\mathrm{R}^{2}\right)$ untuk konstruk dependen dan nilai koefisien path. Nilai $\mathrm{R}^{2}$ digunakan untuk mengukur tingkat variasi perubahan variabel independen terhadap variabel dependen. Semakin tinggi nilai $\mathrm{R}^{2}$ berarti semakin baik model prediksi dari model penelitian yang diajukan. Nilai 
koefisien path digunakan untuk mengetahui tingkat signifikansi dalam pengujian hipotesis. Nilai tersebut diperoleh dari proses bootstrapping. Nilai koefisien path ditunjukkan oleh nilai Tstatistic. Hipotesis terdukung apabila nilai T-statistic > T-table. Nilai T-table yang digunakan pada penelitian ini adalah 1,96[10].

\section{Pembahasan}

Data responden pada penelitian ini diperoleh melalui pengisian kuesioner secara online kepada mahasiswa FMIPA. Total kuesioner terkumpul sebanyak 82 data. Dari jumlah tersebut, 68 responden yang pernah mengakses website UPT Perpustakaan UNILA. Sedangkan, 14 responden belum pernah mengakses website tersebut. Oleh sebab itu, data yang digunakan dalam penelitian ini hanya berasal dari 68 responden.

Analisis data yang dilakukan pertama kali adalah pengujian model pengukuran (outer model). Model pengukuran digunakan untuk menjelaskan hubungan antara variabel laten dengan indikator-indikatornya. Aplikasi yang digunakan pada penelitian ini adalah SmartPLS versi 2.0. Dua parameter yang digunakan dalam model pengukuran yaitu pengujian validitas dan reliabilitas konstruk.

Uji validitas konvergen diukur dengan parameter outer loading, Average Variance Extracted $(A V E)$, dan communality. Suatu indikator dikatakan valid apabila memiliki nilai outer loading lebih dari 0,7, nilai AVE dan communality lebih dari 0,5[10]. Pada proses pengujian awal, diketahui 7 indikator memiliki nilai outer loading kurang dari 0,7. Indikator-indikator tersebut adalah: INT1, INT4, dan INT6 dari konstruk kualitas interaksi layanan (INT); USA1, USA4, USA7, dan USA8 dari konstruk kegunaan (USA). Jogiyanto dan Abdillah [10] dalam bukunya mengatakan, jika indikator memiliki nilai outer loading antara $0,5-0,7$, sebaiknya peneliti tidak menghapus indikator sepanjang nilai AVE dan communality indikator tersebut lebih dari 0,5. Namun, nilai AVE dan communality indikator tersebut, pada pengujian awal kurang dari 0,5. Sehingga, ketujuh indikator tersebut dihapus dan dilakukan pemodelan ulang.

Table 2. Nilai AVE dan Communality pada Model Pengukuran Akhir

\begin{tabular}{ccc}
\hline Variabel & AVE & Communality \\
\hline Information Quality (INF) & 0.583004 & 0.583004 \\
Service Interaction Quality (INT) & 0.586904 & 0.586904 \\
User Satisfaction (KP) & 0.815083 & 0.815083 \\
Usability (USA) & 0.564207 & 0.564207 \\
\hline
\end{tabular}

(Sumber: Hasil pengolahan smartPLS 2.0 (2018))

Hasil pemodelan ulang menunjukkan nilai outer loading sebagian besar telah memiliki nilai lebih dari 0,7, kecuali indikator INT5 dan USA2. Nilai outer loading kedua indikator tersebut adalah 0,684 dan 0,662. Tabel 2 menunjukkan nilai AVE dan communality memiliki nilai lebih dari 0,5. Nilai pada indikator tersebut berada pada nilai toleransi dari outer loading, sehingga seluruh variabel dianggap valid atau telah memenuhi validitas konvergen.

Langkah selanjutnya adalah melakukan pengujian validitas diskriminan. Parameter yang digunakan untuk mengukur validitas diskriminan adalah nilai cross loading. Nilai cross loading, disajikan pada Tabel 3.

Table 3. Hasil Cross Loading

\begin{tabular}{llccc}
\hline Variabel & $\begin{array}{c}\text { Information } \\
\text { Quality (INF) }\end{array}$ & $\begin{array}{c}\text { Service Interaction } \\
\text { Qaulity (INT) }\end{array}$ & $\begin{array}{c}\text { User Satisfaction } \\
\text { (KP) }\end{array}$ & $\begin{array}{c}\text { Usability } \\
\text { (USA) }\end{array}$ \\
\hline
\end{tabular}




\begin{tabular}{cllll}
\hline INF1 & 0.806869 & 0.686542 & 0.577261 & 0.552190 \\
INF2 & 0.808418 & 0.617748 & 0.679671 & 0.540232 \\
INF3 & 0.711164 & 0.676956 & 0.429427 & 0.525749 \\
INF4 & 0.729278 & 0.665805 & 0.497232 & 0.599192 \\
INF5 & 0.787175 & 0.692937 & 0.570538 & 0.523066 \\
INF6 & 0.707849 & 0.558089 & 0.460882 & 0.561130 \\
INF7 & 0.786228 & 0.727082 & 0.630254 & 0.647261 \\
INT2 & 0.681306 & 0.796822 & 0.459749 & 0.461036 \\
INT3 & 0.575362 & 0.768284 & 0.575201 & 0.513646 \\
INT5 & 0.631536 & 0.683773 & 0.309187 & 0.447737 \\
INT7 & 0.767918 & 0.809251 & 0.578197 & 0.543071 \\
KP1 & 0.668577 & 0.616654 & 0.907237 & 0.612039 \\
KP2 & 0.652663 & 0.562269 & 0.898380 & 0.571233 \\
USA2 & 0.492148 & 0.456179 & 0.410111 & 0.682124 \\
USA3 & 0.452113 & 0.396759 & 0.497140 & 0.790156 \\
USA5 & 0.586024 & 0.459441 & 0.493283 & 0.756166 \\
USA6 & 0.665391 & 0.612704 & 0.554603 & 0.771623 \\
\hline SS
\end{tabular}

(Sumber: Hasil pengolahan smartPLS 2.0 (2018))

Berdasarkan Tabel 3, nilai masing-masing indikator yang ada disuatu konstruk memiliki perbedaan dengan indikator di konstruk lain. Hal tersebut ditunjukkan dengan nilai loading yang berada pada kolom berwarna orange memiliki nilai yang lebih tinggi daripada indikator di konstruk lainnya. Dengan demikian, nilai cross loading seluruh indikator telah memenuhi syarat uji validitas diskriminan.

Selajutnya, dilakukan pengujian reliabilitas. Pengujian reliabilitas pada penelitian ini menggunakan dua metode, yaitu cronbach's alpha dan composite reliability. Suatu konstruk dikatakan reliable apabila nilai cronbach's alpha lebih dari 0,6 dan nilai composite reliability lebih dari 0,7[10]. Nilai cronbach's alpha dan composite reliability, disajikan pada Tabel 4. Hasil pada Tabel 4 menunjukkan masing-masing konstruk memiliki nilai lebih dari 0,6 dan 0,7. Hal tersebut dapat dikatakan, seluruh konstruk pada penelitian ini memiliki reliabilitas yang baik

Table 4. Nilai Composite Reliability dan Cronbach's Alpha

\begin{tabular}{ccc}
\hline Variabel & Composite Reliability & Cronbach's Alpha \\
\hline Information Quality (INF) & 0.907046 & 0.880723 \\
Service Interaction Quality (INT) & 0.849845 & 0.769836 \\
User Satisfaction (KP) & 0.898120 & 0.773231 \\
Usability (USA) & 0.837748 & 0.742727 \\
\hline
\end{tabular}

(Sumber: Hasil pengolahan smartPLS 2.0 (2018))

Tahap selanjutnya adalah pengujian model struktural yang dievaluasi menggunakan Coefficient of Determinant $\left(\mathrm{R}^{2}\right)$ untuk konstruk dependen dan nilai koefisien path untuk pengujian hipotesis. Hasil perhitungan SmartPLS 2.0 menunjukkan, nilai $\mathrm{R}^{2}$ untuk variabel KP sebesar 0.566980 . Hal ini berarti, besarnya pengaruh variabel information quality (INF), service interaction quality (INT), dan usability (USA) terhadap variabel user satisfaction (KP) adalah sebesar 0.566980 atau variabel INF, INT, dan USA mampu menjelaskan 56,59\% variabel KP. Secara keseluruhan, nilai $\mathrm{R}^{2}$ yang diperoleh dikatakan baik karena memiliki nilai lebih dari 0,1 [10]. Selanjutnya, untuk menghasilkan nilai koefisien path pada pengujian hipotesis, dilakukan proses bootstrapping. Bootstrapping dilakukan dengan case (jumlah data) sebanyak 68 dan samples yang diiterasi dalam SmartPLS 2.0 sebanyak 200 (default). Hasil bootstrapping dapat 
dilihat pada output SmartPLS 2.0 dalam bentuk report yang berjudul path coefficients. Path coefficients disajikan pada Tabel 5.

Table 5. Path Coefficients

\begin{tabular}{lcc}
\hline Variabel & Original Sample $(\mathbf{O})$ & T Statistics $(\mid \mathbf{O}$ / STERR|) \\
\hline $\mathbf{I N F} \rightarrow$ KP & 0.479230 & 2.144342 \\
$\mathbf{I N T} \rightarrow$ KP & 0.076317 & 0.377281 \\
$\mathbf{U S A} \rightarrow \mathbf{K P}$ & 0.253727 & 2.096021 \\
\hline
\end{tabular}

(Sumber: Hasil pengolahan smartPLS 2.0 (2018))

Pengujian hipotesis dilakukan dengan melihat nilai pada output path coefficients yang diperoleh dari proses bootstrapping pada Tabel 5. Pengujian tersebut dilakukan dengan membandingkan nilai T-statistic dengan nilai T-table. Nilai T-table yang digunakan pada penelitian ini yaitu 1,96. Jika nilai T-statistic lebih tinggi daripada nilai T-table, maka hipotesis terdukung. Berdasarkan Tabel 5 diatas, uji hipotesis dapat dijabarkan sebagai berikut :

1. Hubungan antara kegunaan (usability) dengan kepuasan pengguna (user satisfaction)

$\mathrm{H}_{1}$ : Tidak ada hubungan antara kegunaan dengan kepuasan pengguna

$\mathrm{H}_{2}$ : Terdapat hubungan antara kegunaan dengan kepuasan pengguna

Arah hubungan variabel kegunaan (USA) terhadap variabel kepuasan pengguna (KP) bersifat positif dengan nilai original sample yang dimiliki sebesar 0.253727 . Uji hipotesis yang dilakukan menunjukkan bahwa variabel USA terhadap variabel KP menghasilkan nilai T- statistics sebesar 2.180418. Nilai T-statistics ini lebih besar daripada nilai T-table. Nilai tersebut mengindikasikan terdapat hubungan positif dan signifikan antara variabel kualitas kegunaan dengan variabel kepuasan pengguna. Hal ini berarti hipotesis $\mathrm{H}_{0}$ dalam penelitian ini tidak terdukung.

Hasil penelitian ini sejalan dengan penelitian Sharma dan Lijuan (2015) yang menyatakan kualitas kegunaan berpengaruh terhadap kepuasan pengguna. Semakin baik kualitas kegunaan yang diberikan oleh website UPT Perpustakaan UNILA, maka semakin tinggi tingkat kepuasan pengguna.

2. Hubungan antara kualitas interaksi layanan (service interaction quality) dengan kepuasan pengguna (user satisfaction)

$\mathrm{H}_{1}$ : Tidak ada hubungan antara kualitas interaksi layanan dengan kepuasan pengguna

$\mathrm{H}_{2}$ : Terdapat hubungan antara kualitas interaksi layanan dengan kepuasan pengguna

Arah hubungan variabel kualitas interaksi layanan (INT) terhadap variabel kepuasan pengguna (KP) bersifat positif dengan nilai original sample yang dimiliki sebesar 0.076317 . Uji hipotesis yang dilakukan menunjukkan bahwa variabel INT terhadap variabel KP menghasilkan nilai T- statistics sebesar 0.377281. Nilai T- statistics ini lebih kecil daripada nilai T-table. Nilai tersebut mengindikasikan tidak terdapat hubungan yang signifikan antara variabel kualitas interaksi layanan dengant variabel kepuasan pengguna. Hal ini berarti hipotesis $\mathrm{H}_{0}$ dalam penelitian ini terdukung.

Hasil penelitian ini bertolak belakang dengan penelitian sebelumnya yang mengatakan kualitas interaksi layanan berpengaruh terhadap kepuasan pengguna[7]. Hal ini menunjukkan bahwa kualitas interaksi layanan pada website UPT Perpustakaan UNILA seperti, reputasi 


\section{(C) Ilmu Komputer Unila Publishing Network all right reserve}

website yang baik, keamanan dalam bertransaksi dan menjaga informasi pribadi, rasa personalisasi, adanya suasana komunitas, kemudahan dalam berkomunikasi dengan organisasi (pengelola website), dan tingkat kepercayaan layanan/informasi yang diberikan tidak mempengaruhi kepuasan pengguna.

3. Hubungan antara kualitas informasi (information quality) dengan kepuasan pengguna (user satisfaction)

$\mathrm{H}_{1}$ : Tidak ada hubungan antara kualitas informasi dengan kepuasan pengguna

$\mathrm{H}_{2}$ : Terdapat hubungan antara kualitas informasi dengan kepuasan pengguna

Arah hubungan variabel kualitas informasi (INF) terhadap variabel kepuasan pengguna (KP) bersifat positif dengan nilai original sample yang dimiliki sebesar 0.479230. Uji hipotesis yang dilakukan menunjukkan bahwa variabel INF terhadap variabel KP menghasilkan nilai T- statistics sebesar 2.144342. Nilai T- statistics ini lebih besar daripada nilai T-table. Nilai tersebut mengindikasikan terdapat hubungan positif dan signifikan antara variabel kualitas informasi dengan variabel kepuasan pengguna. Hal ini berarti hipotesis $\mathrm{H}_{0}$ dalam penelitian ini tidak terdukung.

Hasil penelitian ini sejalan dengan penelitian Masrek dan Gaskin[8] yang menyatakan kualitas informasi berpengaruh terhadap kepuasan pengguna. Shaltoni et al[9] juga menyatakan kualitas informasi dianggap penting karena memberikan informasi yang berkualitas kepada pengguna secara konsisten dipandang sebagai penentu utama website tersebut dapat diterima oleh pengguna. Semakin baik kualitas informasi yang diberikan oleh website UPT Perpustakaan UNILA, maka semakin tinggi tingkat kepuasan pengguna.

\section{Kesimpulan}

Berdasarkan hasil penelitian yang telah dilakukan, maka dapat disimpulkan sebagai berikut.

- Terdapat hubungan positif dan signifikan antara kualitas informasi dengan kepuasan pengguna. Semakin baik kualitas informasi yang diberikan website UPT Perpustakaan UNILA, maka semakin tinggi tingkat kepuasan pengguna.

- Tidak terdapat hubungan yang signifikan antara kualitas interaksi layanan dengan kepuasan pengguna. Kualitas interaksi layanan yang diberikan website UPT Perpustakaan UNILA tidak mempengaruhi kepuasan pengguna.

- Terdapat hubungan positif dan signifikan antara kegunaan dengan kepuasan pengguna. Semakin baik kualitas kegunaan yang diberikan website UPT Perpustakaan UNILA, maka semakin tinggi tingkat kepuasan pengguna.

\section{DAFTAR PUSTAKA}

[1] W. H. DeLone and E. R. McLean, "The DeLone and McLean Model of Information Systems Success : A Ten-Year Update," J. Manag. Inf. Syst., vol. 19, no. 4, pp. 9-30, 2003.

[2] S. J. Barnes and R. T. Vidgen, "Assessing the quality of auction web sites," Proc. Hawaii Int. Conf. Syst. Sci., p. 189, 2001. 
[3] S. J. Barnes and R. T. Vidgen, "an Integrative Approach To the Assessment of ECommerce Quality," no. August 1998, pp. 114-127, 2002.

[4] J. Tarigan, "User Satisfaction Using Webqual Instrument : A Research on Stock Exchange of Thailand ( SET )," J. Akutansi dan Keuang., vol. 10, pp. 34-47, 2008.

[5] S. Barnes and R. Vidgen, "WebQual : An Exploration of Web-site Quality," Communications, vol. 1, pp. 298-305, 2000.

[6] L. Xiao and S. Dasgupta, "Measurement of user satisfaction with web-based information systems: An empirical study," Proc. Eighth Am. Conf. Inf. Syst. Human-Computer Interact. Stud. MIS, pp. 1149-1155, 2002.

[7] G. Sharma and W. Lijuan, "The effects of online service quality of e-commerce Websites on user satisfaction," Electron. Libr., vol. 33, no. 3, pp. 468-485, 2015.

[8] M. N. Masrek and J. E. Gaskin, "Assessing users satisfaction with web digital library: the case of Universiti Teknologi MARA," Int. J. Inf. Learn. Technol., vol. 33, no. 1, pp. 36-56, 2016.

[9] A. M. Shaltoni, H. Khraim, A. Abuhamad, and M. Amer, "Exploring students' satisfaction with universities' portals in developing countries," Int. J. Inf. Learn. Technol., vol. 32, no. 2, pp. 82-93, 2015.

[10] Jogiyanto and W. Abdillah, Konsep dan Aplikasi PLS (Partial Least Square) Untuk Penelitian Empiris. Yogyakarta: BPFE-Yogyakarta, 2016. 